\title{
Household Wealth as a Factor of Economic Growth: A Case Study of Italy
}

lacopo Odoardi and Carmen Pagliari

ABSTRACT

\begin{abstract}
The wealth possessed by households, identifiable as so-called net worth, varies greatly in quantity and form between different socioeconomic contexts. We describe several forms of wealth typically owned by consumer households, considering their economic and social effects. We analyze the economic role of the wealth forms that compose the households' net worth (real and financial assets minus the debt) in a panel data analysis of Italian regions, and we suggest a possible alternative use for a specific part of household net worth. In particular, the well-known financial share is already useful and exploited by the economic system, as confirmed empirically. Instead, a share of the real assets could prove useful as a source of support for the economy if some conditions are met. The results of the regional analysis illustrate the supposed lack of contribution and we suggest how the net worth not "fully exploited" could be integrated in the economic cycle, activating a propulsive mechanism to start "accelerated" growth processes.
\end{abstract}

KEY WORDS: $\quad$ household wealth, economic growth, panel data analysis.

JEL Classification: E21, O47.

University of Chieti-Pescara, Italy

\section{Introduction}

Household wealth is a significant "economic resource" (Vecchi, 2017) composed of different types of assets, which in some cases can be not fully exploited for economic purposes. Limits to its complete exploitation lie both in the misperception regarding the quantification of this resource and the actual convenience in its use.

We must consider that several definitions of wealth exist, and they sometimes conflict with each other. Furthermore, it is very difficult to collect detailed quantitative information on the composition of household wealth (see Juster et al., 1999). We suggest that wealth must be better exploited because it plays an

Correspondence concerning this article should be addressed to: Iacopo Odoardi, University of Chieti-Pescara, Italy. E-mail: iacopo.odoardi@unich.it. important role in influencing other macroeconomic variables. For example, Bertaut (2002) found strong economic effects of wealth on consumption in the US, Canada and Japan and a weaker effect in Europe. Carroll et al. (2011) distinguished the effects, both positive, of the increments in housing wealth and financial wealth, focusing on the type that supported the strength of consumption in the US in the early 2000s, and Cooper and Dynan (2016) highlighted that wealth has more pronounced effects on consumption for households facing credit constraints. The role of wealth is also studied in developing countries. For example, Langyintuo and Mungoma (2008) studied the influence of household wealth on the adoption of new technologies in Zambia, and Hong et al. (2006) found that household wealth strongly influences the growth rate of children in Bangladesh. Accordingly, 
the different factors influencing wealth must be better analyzed to promote its accumulation; these factors include, among others, the presence of social security programs (Feldstein \& Pellechio, 1979), financial literacy (van Rooij et al., 2012), inheritance bequests, the propensity to engage in homeownership (Mathä et al., 2017), house price fluctuations (Bao \& $\mathrm{Li}, 2017$ ), the effects of underground economy (Odoardi \& Pagliari, 2011 ) and factors related to racial inequalities (Keister, 2000).

In this study, the first aim is to describe wealth as analyzed in various forms in the economic literature, considering the characteristics of wealth usually associated with the assets of consumer households. These steps serve to clarify the forms and possible functions that wealth can have, particularly the forms of household net worth. Our aim is to study how different types of wealth influence economic performance and hypothesize how specific types of wealth represent a resource not used efficiently for economic growth. Of course, other wealth components already play an important role, according to their characteristics and the context in which they are present. With this aim, we gradually focus on the alternative uses of "nonproductive" wealth to provide policy suggestions.

The wealth available to households can be considered a productive resource if combined with policy interventions to encourage its accumulation and use. In order to define appropriate interventions, it is necessary to investigate the types of wealth most useful according to each socioeconomic context.

After describing diverse types of wealth, the characteristics of the forms typically held by households are discussed to determine whether specific assets can be efficiently utilized, e.g., exploited for productive purposes. In addition, we propose to consider some similarities and connections between income and wealth with the aim of describing numerous aspects of wealth not directly observable for the scarcity of empirical studies. Income and its distribution have, in some cases, characteristics similar to those of the wealth forms that compose the households' net worth (real and financial assets minus the debt). In this sense, we avoid considering wealth equal to the current or future income and that intended as productive capital rather than savings that are managed by the banking channel.

A panel data analysis is used to test the effect of the components of household net worth on the regional economic performances in the Italian context. Our case study is a context in which families traditionally have a high liking for home ownership and savings, maintaining a low level of indebtedness. The fixed effects (FE) and random effects (RE) models are used to analyze regional data (2004-2014).

After an overview of the forms and estimation of wealth in Section 2.1, Section 2.2 illustrates some characteristics of this economic resource, and Section 2.3 explains the relationship between wealth and income with a focus on human capital, which is an essential factor to foster economic growth in advanced economies. Section 2.4 proposes an international comparison by discussing some relevant features of wealth in different countries. Sections 3 and 4 relay the description of the methods and the data used in the analysis. The results of the regional analysis are presented in Section 5. The paper concludes with the policy implications and the conclusions.

\section{Literature Review}

Many definitions of wealth exist. Definitions are influenced by the fact that there are regularities in the form in which wealth is held, but at the same time, strong regional specificities exist (see, among others, Davies et al., 2011). For example, material wealth (e.g., arable land and agricultural tools) is the most desirable form in less developed or developing countries because of the presence of an inefficient financial system. In such situations, the distribution of income also plays a key role by allowing the accumulation of productive capital (which in backward economies is connected with the wealth/capital stock accumulation). Of course, we mean "capital" as a set of productive tools useful to businesses for productive activities. It differs from the more generic "wealth" that can include the means of production and material goods and that can even attain financial assets and intangible and relational elements (as the ability to generate future income, the relationships in the social group, the level of human capital). We refer to households as typical economic agents, but they are not the only holders of wealth in a non-productive manner.

Definitions should consider that the composition of wealth changes over time, differs between countries and is influenced by specific patterns of consumption 
and investment of different social classes. Definitions suggest that dissimilar categories of tangible and intangible assets can be involved. For example, Borgerhoff Mulder et al. (2009) focus on wealth inequality and its transmissibility among generations by dividing the socioeconomic contexts according to the different nature of their economic activities and their "social rules". They observe that different types of wealth, heritable or not, affect the future well-being of children in the absence of alleged general rules, with the underlying condition that passed-on wealth would have some utility, fitting or not for the context in which it would be used. From this perspective, wealth is explained in three forms: embodied wealth (the physical qualities transmitted genetically from parents, the propensity to socialize and transmissible knowledge), material wealth (physically transmissible goods, which are useful for increasing the well-being of an individual) and relational wealth (such as social networks). This classification introduces the consideration of immaterial wealth and highlights how there are types of wealth that are more useful in certain contexts (e.g., agricultural tools in rural contexts) and forms of wealth easily obtainable even if not transmittable (e.g., social relationships).

Other definitions are those synthesized by Wolff (1990; 1996). According to these descriptions of household wealth, we distinguish disposable wealth (assets and liabilities that have a current market value, such as real estate, cash and financial instruments), augmented wealth (a broader definition that includes the value of future flows of revenue, values such as social security or retirement pension and possible future earnings due to the level of personal human capital) and capital wealth (the sum of deposits, bonds, business equity and other types of securities). Wolff (1990) suggests that the latter type (see also Kessler \& Masson, 1987; Wolff, 1981;) differs from the previous ones by being almost exclusively owned by the richest classes, who thereby maintain the benefits of controlling the funds and the means of production across the generations. For example, it is generally accepted that a purpose of all organizations is to maximize the wealth of their owners or shareholders (Cardao-Pito, 2017), thus influencing the net worth of only some categories of individuals.

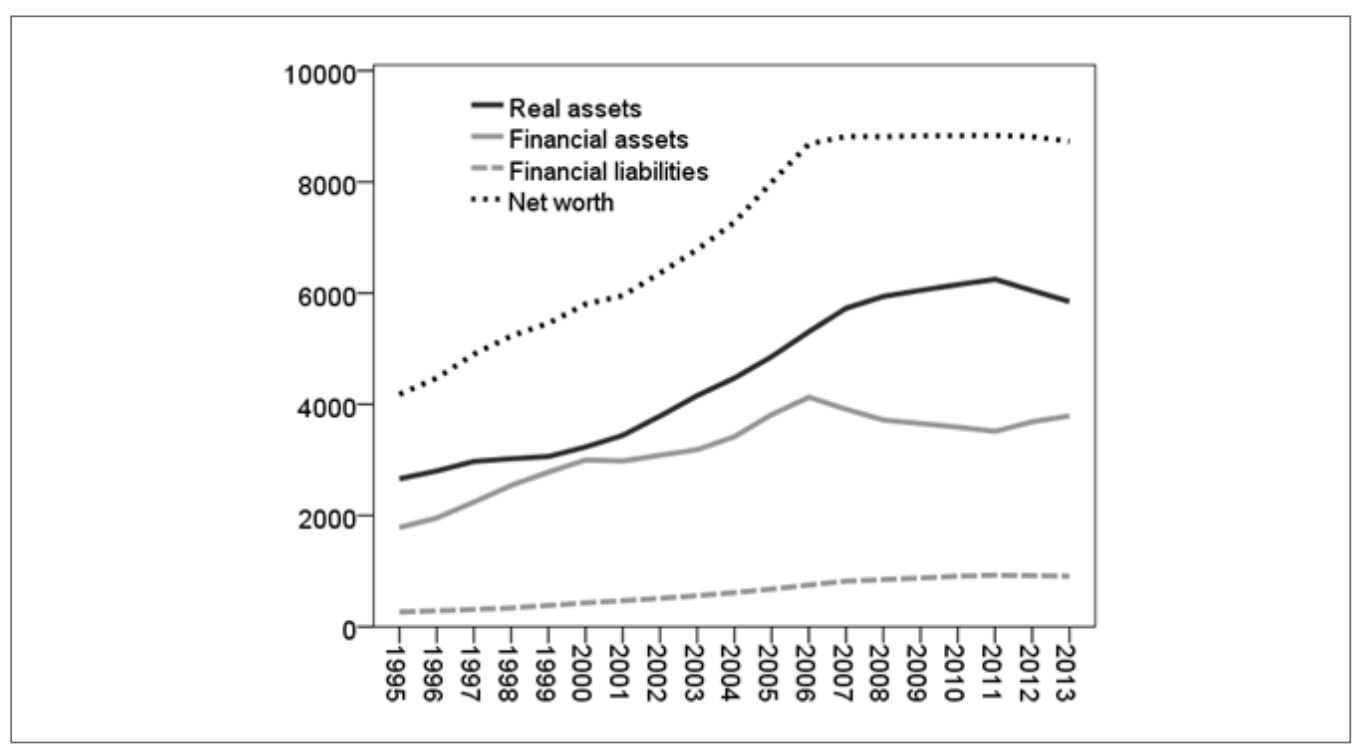

Figure 1. Net worth of Italian households and its main components (billions of current Euro, 1995-2013). 
In addition to defining wealth, an important step is to estimate its value and its composition at the household level, i.e., the so-called "portfolio choices," prior to estimating the economic effects. As happens for the different definitions, contrasting findings exist for wealth components. For example, human capital obtained through investment in education seems an effective component for Bos (2011); therefore, it differs from the usual net worth. However, e.g., Buiter (2010) does not consider housing or property as a wealth component. Contrarily, the increased presence of houses in the composition of the middle-class households' portfolios is considered one of the causes of the increased net worth inequality during the Great Recession in the US (Wolff, 2014a). However, US households have a scarce preference for non-financial assets (Piketty, 2014) due, for example, to the high mobility of workers. Instead, the weight of the house component is particularly relevant in the Italian case, as shown in Figure 1. We show the composition of the portfolio of Italian households using data from the Bank of Italy.

In Figure 1, we note the relevance of the house in the Italians' preferences for real assets, and we also observe the effects of the 2007 crisis with an increase in indebtedness. Subsequently, the failure of economic recovery from 2009-2010 and the prolonged recession have changed the traditional preferences of Italians towards the housing investment. However, homeownership is a relevant factor influencing wealth levels, and it varies greatly among countries, as Mathä et al. (2017) shows it to vary among the European countries from $44 \%$ in Germany to $90 \%$ in Slovakia.

It is important also to consider that wealth plays a role in influencing the choices of consumer households in a manner similar to disposable income. In fact, wealth is an important support to consumption (Aron \& Muellbauer, 2013), saving and investment choices, therefore affecting the welfare of economic agents and, at the aggregate level, influencing the economic growth path. In this sense, wealth appears to be determinant in conditioning consumption, as occurs during phases of decreasing income (Jäntti \& Sierminska, 2007). Conversely, income distribution plays a definite role in determining the way in which wealth is shaped and consequently used efficiently.

\subsection{Some Limits in the Quantitative Estima- tion of Wealth}

It is difficult to estimate the value and the endowment of an economic variable which is sometimes vaguely defined. The typical indicator of household wealth is the estimate of the net worth, for which there are systematic measurements for some countries (e.g., Bank of Italy, 2015), surveys (see Juster et al., 1999) and studies on inequality (Wolff, 2014b). Indeed, even the official statistics on the levels and distribution of income are scarce in many countries. If high-quality data on income (and wealth) distribution are scarce, the consumption levels can be used as a proxy variable. It might be considered appropriate to test what is actually "consumed" by the population in a broader sense, which therefore affects its welfare. The consumption level is easier to assess through specific surveys (often it is easier to gather information on consumption than on taxable income), especially in the poorest rural contexts, where barter is pervasive and the "income/agricultural product" is directly consumed.

Data reconstructions affect studies on wealth because researchers can use proxy variables (see Aghion et al., 1999) such as the inequality of income (Perotti, 1996) and the distribution of land (Alesina \& Rodrik, 1994). The latter type, being relevant for studying the distribution of income, could also be considered for wealth. We refer to the policy reforms for the redistribution of land that occurred in some Asian Countries after World War II, leading to a socio-political and economic climate of peace, which allowed high rates of durable growth (among others, Alesina \& Perotti, 1996).

Conflicting results may occur if we use more variables or different datasets or if we compare diverse estimation techniques or we consider groups of countries with different socioeconomic characteristics (Neves and Silva, 2014).

\subsection{Some Characteristics of Wealth as an Eco- nomic Resource}

Accumulated wealth varies in different contexts and historical periods because each form has a different degree of transferability and utility when passed between generations. Mathä et al. (2017), for example, have found strong differences among 
European countries in the wealth level but also fundamental common aspects, such as the influences of homeownership, the value appreciation of the houses and the intergenerational transfers.

As Arrondel and Grange (2006) argue, inheritance may consist of different forms of capital, such as cultural, social, symbolic and economic, that can be transferred with dissimilar shapes and intensities. The nature of bequests and their usefulness are other critical factors of inequality (for an analysis of inheritance and economic conditions see Cooper \& Bird, 2012). For Semyonov and Lewin-Epstein (2013, on a cross-country analysis), the transfers between generations, together with the income, are the main factors of wealth accumulation. It must be considered that the possibility of accumulation, and thus the decisions concerning the transmission of wealth, vary considerably among societies for reasons related to practices and traditions (see De Nardi, 2004; Morgan \& Scott, 2007). Obviously, the historical changes in quantitative levels of wealth originated and available affect the average values inherited (see Wolff \& Gittleman, 2014, for the US), thereby suggesting constant increments at least in the Western economies. Wealth distribution is continuously changing over time. For example, Saez and Zucman (2016) found that wealth concentration was high at the beginning of the twentieth century in the US, while the trend reversed during the period 1929-1978 and returned to steadily increase since then. In this case, the Authors attribute the changes to the increase in higher incomes and the major inequality in savings rates.

The progressive accumulation of wealth across generations may increase the level of inequality, even if the distribution of inheritance is distinct and not always linked to the income differentials of those inheriting. For example, Horioka (2009), in the Japanese case, excludes the need for a specific tax on inheritance in order to promote equality because, in that country, bequests are related to a request for a return in terms of utility (e.g., assistance to elderly parents) representing a value that should be subtracted from the inherited wealth. Gokhale et al. (2001) observe that bequests are not directly connected with differences in income and do not always induce the growth of inequality.

\subsection{Income and Wealth, Differences and Relations}

In general, the form and the value of household wealth depend on both wealth and income distributions, influencing consumption and saving behaviors. Therefore, all the aspects of income inequality in the socioeconomic sense must be considered.

Since the 1950s, the idea of a relationship between inequality and economic growth (e.g., Kuznets, 1955; Kaldor, 1955) has emerged (Alesina \& Perotti, 1996; Barro \& Sala-i-Martin, 1995; Clarke, 1995; Deininger \& Squire, 1998; Easterly, 2007; Galor \& Moav, 2004; Grossmann, 2008). However, driven by alternative arguments of policymakers, researchers faced a dilemma: protect and support economic growth or use the available resources bringing the country toward a situation of greater social equality. Until the 1960s, it was generally believed that the search for greater social equality, however desirable, negatively affected the efforts to support economic growth. The economic theory related to these issues was revised in the period following World War II, in which some Asian nations reached good levels of economic growth and, at the same time, a moderate level of social equality. As already argued by the studies of the 1950s, this positive effect is due to the possibility of stimulating different and complementary types of investment related to physical capital and human capital by affecting the degree of distribution of new resources within a system.

There is a similarity between changes in the inequalities of income and wealth attributable to specific shocks. The fluctuations in income might be determined by the fact that different causes and intensities of variations in wages (earnings) and income from capital are present (Aghion et al., 1999). For example, Barceló and Villanueva (2016) prove that the type of employment contract affects the ability to accumulate wealth considering the possibility in changes in job security, and older workers with fixedterm contracts accumulate more financial wealth.

The different types of income are specific to different social classes, and changes not correlated with different types of income can amplify inequalities. However, entrepreneurs/capitalists and consumer households/workers can earn more types of income (and wealth) (Pasinetti, 1962). For wealth, the possibility and the willingness of accumulation are decisive, as is its possible use for the future 
generations. While the rules of accumulation over time are similar, the shocks are different for specific categories and social classes. If a high degree of transmissibility of wealth is present, then inequality is perpetuated through bequests, but it is also true that shocks affect wealth as a heritage for several generations (Borgerhoff Mulder et al., 2009).

Another common aspect regarding income and wealth concerns the constraints posed by the so-called imperfections in the credit market (Bhattacharya, 1998; Boyd \& Smith, 1997; Cartiglia, 1997; Ma \& Smith, 1996; ), asymmetric information and limits to the action of credit institutions. The access to credit, studied through proxy variables such as the loans granted, is a fundamental determinant of economic growth in the sense that a greater possibility to obtain resources would support the processes of consumption and investment (among others, Aghion et al., 1999). When the credit market suffers from limitations, many individuals can not improve their original status rebalancing the situation in the field of equality and welfare (Benabou, 2000). This situation occurs more frequently in developing countries, characterized by an inadequate domestic financial market, low-income levels and few holders of "useful" wealth because there is often a greater concentration of wealth compared to that of income (Jäntti \& Sierminska, 2007; Davies et al., 2011). The higher polarization of wealth is demonstrated by the estimates for the Gini index of income and wealth globally (for income see Milanovic, 2005; for wealth see Davies et al., 2011), which means that in countries where the wealth would have an even greater relative value, the useful resources are available at lower levels than the already low average income, compared to the western "rich" countries.

The highest inequality in wealth distribution (compared to income) is not always effective. Ward (2014) proves that, despite an increase in the Chinese income inequality, both wealth and the consequent welfare level have improved for the population due to the economic growth and reducing inequality at least in the wealth sense.

The above mentioned credit market imperfection and inequalities play a relevant role, especially in less developed countries, by having a considerable impact on the accumulation of human capital.
Income and wealth must be homogeneously distributed to promote human capital formation (therefore sufficient resources to larger segments of the population) so that households may invest in education and training (among many studies, see Eicher \& Garcia-Penalosa, 2001; Galor \&Zeira, 1993;; Galor \& Moav, 2004). On the contrary, Grossman (2008) argues that the unequal distribution of wealth among households contributes substantially to increasing human capital in the absence of credit constraints, with positive effects on the economy. A limitation, as mentioned, is the assumption of the lack of restrictions due to imperfections in the credit market, at least with regard to investment in education (Cartiglia, 1997; Carneiro et al., 2003).

The relationship is similar in rich countries. Lovenheim (2011) demonstrates that housing wealth, and particularly its liquid forms, are used to sustain postsecondary school enrollment in the US, and if the housing boom has favored this phenomenon in the past, the subsequent credit constraints and the effects of the 2007 crisis could damage the level of education for the less wealthy households.

To illustrate the relationship between the level of education and wealth, we show the values of several educational levels and the net worth at the household level in the US for selected years.

Figure 2 shows a clear division in the absolute value of the net worth of the person with (letter D in the upper part of the graph) and without a college degree. Furthermore, we note that the 2013 values (during the Great Recession) are lower than in the previous decade and especially the 2007 value, just before the burst of the speculative bubble in the US. At the same time, the mean net worth is lower than the median in the post-crisis period suggesting that the distribution values are more concentrated in the lower part with respect to the center point.

In addition to the availability of economic resources, the willingness to invest in education and vocational training is influenced by risk awareness. The "risk" of investing in education is another common issue linking income and wealth (Grossmann, 2008). In fact, the possibility to provide high-quality education to children based on income and wealth sources induces a sort of "transmission 
of human capital" from a generation to the next one (Becker \& Tomes, 1979; Tomes, 1981). The risk of investing in education is compensated by the return through a sort of "education premium," i.e., to possess high skills and thus to earn more in future (Cartiglia, 1997; Carneiro et al., 2003) and therefore accumulate greater wealth, as represented by Figure 2. For Filmer and Pritchett (1999), this issue also concerns school dropouts from the poorest part of the populations and the median years of school completed, which can range from one to two years and up to ten, in different countries between the rich and the poor social classes.

\subsection{A Look at Other Countries: The Determinants of the Different Forms and Values of Wealth}

The wealth of households greatly depends on savings rates and the latter greatly vary among countries. The differences are due to the levels of income and savings opportunities, but also to demographic composition, local financial systems, welfare levels and social programs (Poterba, 1994). The reasons why people save influence disposable wealth (Deaton, 1992). For example, Yao et al. (2011) show that Chinese households are more inclined to save than American ones for education or precautionary reasons, and the poorest ones for pension reasons. Wealth accumulation also depends on family habits, as highlighted by Friedline et al. (2014) on US data, since the individuals who grew up in families with a high and stable net worth are more inclined to accumulate wealth (in particular of a financial nature). Thus, the habit of accumulating wealth from the young age will influence the trend along life (Kim et al., 2011). In adulthood, the composition of families and, in particular, the presence of marriedcouple households lead to accumulating a higher net worth; but also other factors impact on wealth levels, such as the ethnicity, the educational status of the householder, and the number and age of children (Grinstein-Weiss et al., 2008, on the US). For example, Brown and Taylor (2008) found that the

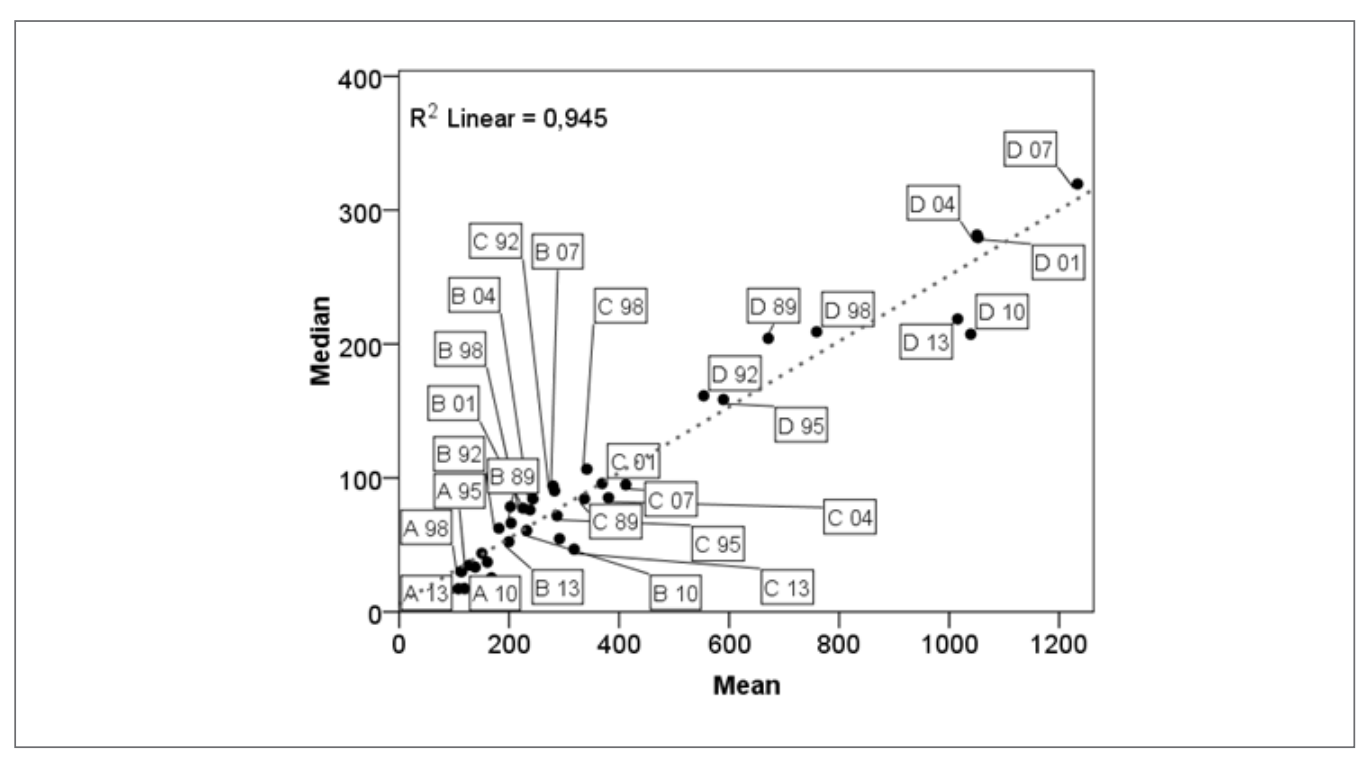

Figure 2. Mean and median net worth of the US households by educational attainment of selected years (Thousands of 2013 Dollars; $A=$ No high school diploma, B=High school diploma, $C=$ Some college, $D=$ College degree). 
poorest and the youngest households - from survey data on the US, the UK and Germany - are those more exposed to adverse changes in their financial circumstances. For the same reason, households with one parent and, in particular, female-headed households show significantly lower levels of net worth (Ozawa \& Lee, 2006). Habits and (mainly savings) behaviors, together with different pension systems, strongly influence also the level and availability of wealth in the years of retirement (Gale, 1998, on the US).

However, other relevant individual characteristics influence wealth and its composition. For example, Renneboog and Spaenjers (2012) found that differences in saving behaviors exist between Dutch religious and non-religious households - the first group tends to plan on long-term horizons - and that differences based on the type of religion also exist. Van Rooij et al. (2012, on the Netherlands) found that, more than education in general, financial literacy influence the level of household wealth, e.g., by favoring investments in the stock market and influencing retirement planning behavior. Among the structural causes, Xie and Jin (2015) found that urban-rural divide and regional economic disparities, together with institutional factors, strongly affect the wealth of the households in Chinese provinces.

With the aim of observing the relationship between income and wealth in a cross-country approach, we use a graphical representation where the household net worth is measured as a percentage of net disposable income (source: OECD) and is compared to the GDP per capita (source: IMF), chosen as a proxy of the income level. Data are from 2014, which is the year for which the values of wealth are available for the greatest number of countries.

In Figure 3, we observe that there is a direct relationship between the tendency to accumulate wealth and the income level. Of course, the diverse composition of net worth (e.g., Babeau \& Sbano, 2003) and the different concentration (Davies et al., 2011) are at the base of this relationship differently. For example, Kessler and Wolff (1991) found greater inequality in the US than in France but also a different composition in the latter country, in particular, a major percentage of owner-occupied housing and a minor proportion of corporate stock and financial se- curities. The number of owner-occupied housing and the structure of the family in general is at the base both of the wealth and of its distribution, as tested by Bover (2010) comparing Spanish and US households. In Italy, the percentage of wealth on disposable income is similar to that of countries with a $40 \%$ higher income (Canada, US). This result is also due to the low level of indebtedness of Italian households, as highlighted by Davies et al. (2011). Of course, the considered period includes the 2007 financial crisis and unexpected events are responsible for shocks on income and wealth levels, and Mian et al. (2013) show that these effects happen in a not homogeneous way (as tested on the US) due to the different wealth levels and to the not homogeneous negative effects on individuals.

\section{Methods}

We use fixed and random effects models (see Bell and Jones, 2015, for a comparison between the two models) to find relationships between variables within groups (see Elhorst, 2014). In the FE model, the individual effects are considered fixed and are included among the explanatory variables as individual constants, while estimated individual effects are a component of the error in $\mathrm{RE}$, which implies that the two models can provide different results, depending on the data used in the analysis. The Hausman test (1978) gives us information on what output has the best fit.

Our equation can be written as:

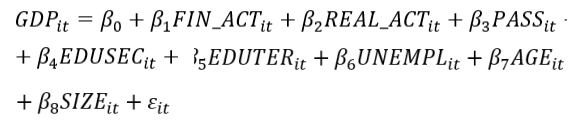

in which the dependent variable is the GDP per capita and the independent variable are discussed in the literature survey and presented in Section 4. In particular, FIN_ACT, REAL_ACT and PASS are the three components that form household net worth, a proxy of wealth level. We consider the 20 Italian regions $(i)$, and the period $(t)$ is $2004-2014 ; \beta_{00}, \ldots, \beta_{8}$ are the parameters estimated and $\varepsilon_{i t}$ is the error term.

Although we want to suggest an alternative use of part of wealth to promote economic growth, we do not present a regional growth model with the characteristics of an augmented Solow model (Mankiw et al., 
1992). The period analyzed by us is short and not representative because it contains the period of economic crisis. Furthermore, the selected variables are suggested by the literature previously described and are not those usually analyzed in economic growth models.

\section{Data}

The variable representing the regional economic performances is GDP per capita (Greco et al., 2018). We consider the constant 2010 value to avoid the influence of inflation.

The selected independent variables are connected to income and wealth. Among the independent variables, our focus is on the three main components of household wealth, i.e., real and financial assets and financial liabilities. Data on household wealth is used, among others, by Campbell (2006) and Guiso and Sodini (2013). Starting from the economic literature reviewed herein, we consider wealth as the sum of movable and immovable properties (in some way usable for production purposes) and financial assets held by economic agents (minus debts). The purpose of providing policy indications in this study requires choosing this definition because it is appropriate to consider the alternative uses of wealth not fully exploited by the possessors.

We expect that the first two values positively influence the local GDP, in particular the portion of financial assets that is most easily inserted in the production cycles, while the real part, as discussed in this article, cannot currently play an important role (and contains houses).

The other independent variables are used to test the robustness of the results. Human capital is a well-known determinant of economic performance in advanced countries, particularly at the regional level (Crescenzi et al., 2016). We consider the highest levels of education that should be relevant in advanced economies (Hanushek \& Woessmann, 2012), even if the economic literature does not always find a positive effect at the regional level in Italy (Odoardi \& Muratore, 2019a; 2019b;

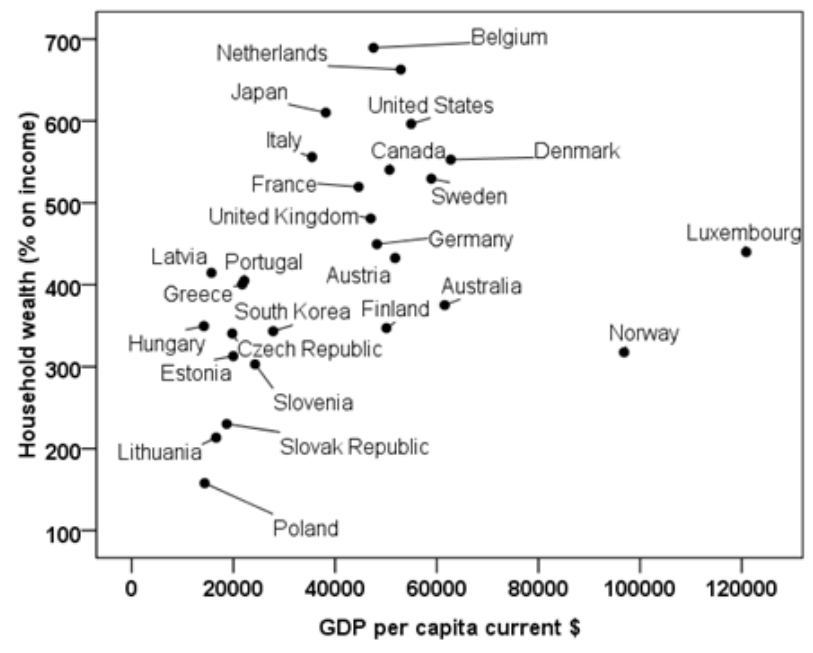

Figure 3. Relationship between the GDP per capita (at current US dollars) and the household wealth (measured as \% of income) in selected countries, 2014. 
Di Liberto, 2008). The unemployment rate, in addition to being one of the proxies used to measure the level of well-being and give information on regional disparities (Stewart, 2005), can also be considered a proxy for the labor market (Fagerberg \& Verspagen, 1996). Finally, average age (see Juselius \& Takáts, 2015) and the size of families are regional characteristics that vary among the Italian regions and, in general, affect income and wealth formation opportunities, as discussed in Section 2. For example, the average age in the Center-North of the country is 44.57 , and the size of the families is 2.29 members; in the South, they are 42.33 and 2.57 , respectively (our elaborations on Istat data). All the variables are defined in Table 1. We propose the summary statistics of the dependent and independent variables in Table 2 .

As expected, we observe a greater share of real assets (which, in Italy, have an average value equal to almost twice that of financial wealth), which also include the value of real estate where families live, since approximately $80 \%$ of Italian households own the house in which they live (Istat, 2017; for more information on Italian households wealth see Brandolini et al., 2004).

\section{Results}

Fixed and random effects models are often used in regional analysis (e.g., Démurger, 2001; Brun et al., 2002). We present the results in Table 3 followed

Table 1. Variable Descriptions and Sources

\begin{tabular}{|c|c|c|}
\hline Variable & Definition & Source \\
\hline GDP & GDP per capita, constant 2010 values (euro) & Istat \\
\hline FIN_ACT & $\begin{array}{l}\text { household financial assets (financial assets divided by } \\
\text { the number of residential households, in Euro) }\end{array}$ & Bank of Italy and Istat (our elaborations) \\
\hline REAL_ACT & $\begin{array}{l}\text { household real assets (real assets divided by the num- } \\
\text { ber of residential households, in Euro) }\end{array}$ & Bank of Italy and Istat (our elaborations) \\
\hline PASS & $\begin{array}{l}\text { household financial liabilities (financial liabilities divid- } \\
\text { ed by the number of residential households, in Euro) }\end{array}$ & Bank of Italy and Istat (our elaborations) \\
\hline EDUSEC & $\begin{array}{l}\text { population aged } 25-64 \text { with upper secondary and } \\
\text { post-secondary non-tertiary education (levels 3-4 } \\
\text { ISCED } 2011, \% \text { ) }\end{array}$ & Eurostat \\
\hline EDUTER & $\begin{array}{l}\text { population aged 25-64 with tertiary education (levels } \\
5-8 \text { ISCED } 2011, \%)\end{array}$ & Eurostat \\
\hline UNEMPL & unemployment rate (15 years and over, \%) & Istat \\
\hline AGE & average age of the population (years) & Istat \\
\hline SIZE & average number of components per family & Istat \\
\hline
\end{tabular}

Note: ${ }^{a}$ International Standard Classification of Education. 
Table 2. Summary Statistics (2004-2014)

\begin{tabular}{|c|c|c|c|c|}
\hline & Min & Max & Mean & St. Dev. \\
\hline GDP & 15309.53 & 36892.29 & 26223.70 & 6622.90 \\
\hline FIN_ACT & 71912.27 & 261301.93 & 137051.35 & 44458.81 \\
\hline REAL_ACT & 110092.94 & 516448.79 & 248571.90 & 86770.32 \\
\hline PASS & 17439.40 & 48068.36 & 31669.83 & 7490.09 \\
\hline EDUSEC & 29.50 & 51.14 & 40.19 & 4.72 \\
\hline EDUTER & 9.20 & 23.30 & 14.29 & 2.61 \\
\hline UNEMPL & 2.75 & 23.42 & 8.95 & 4.70 \\
\hline AGE & 38.30 & 48.10 & 43.67 & 1.94 \\
\hline SIZE & 1.97 & 2.90 & 2.40 & 0.20 \\
\hline
\end{tabular}

Source: Authors' elaboration based on Bank of Italy, Eurostat and Istat data.

by the Hausman (1978) test. We expect to observe a better fitting of the FE model because all the regions are considered, and their number is relatively low.

The Hausman test rejects random effects; thus, we consider the FE results. The only component of household net worth that has a statistical significance is financial wealth, which of course by its nature is already exploited and introduced into the economic and production systems (Dębski \& Świderski, 2016). An important aspect is its coefficient, which should induce policy makers to favor the accumulation of private wealth to promote local and national economic development. The signs of the other two components (positive for financial wealth and negative for liabilities) are as expected but not relevant.

Considering the control variable, the negative relationship between tertiary education and the dependent variable is a negative signal for Italian development but it is also an expected relationship (Di Liberto, 2008) which derives from inability to exploit the returns from education, low labor productivity, and also high school dropout and an increasing NEET rate in several regions (Odoardi et al., 2018). Unemployment rate is closely related to GDP per capita and obviously the sign is negative, while family size shows a direct relationship.

In synthesis, the influence of the wealth accumulated by households is therefore positive, at least for the part directly "exploitable" by the system. However, a large part of it consists of real assets and, in turn, a large proportion of these assets represent the residential house. The other real assets could otherwise be used with appropriate policy interventions regarding their more efficient use. We observe that in contemporary economic systems, as in the past, there are real properties and their rents (or other derived financial wealth) that are held in a "non-productive" way for the economic system, although they are "potentially productive". In Italy, for example, residential houses are the $51 \%$ of total household assets and just over 
Table 3. FE and RE results for Italy (2004-2014)

\begin{tabular}{|c|c|c|}
\hline & FE & RE \\
\hline \multirow[t]{2}{*}{ FIN_ACT } & $0.1854^{* * *}$ & $0.0588^{* * *}$ \\
\hline & $(0.0054)$ & $(0.0059)$ \\
\hline \multirow[t]{2}{*}{ REAL_ACT } & 0.0013 & 0.0032 \\
\hline & $(0.0031)$ & $(0.0032)$ \\
\hline \multirow[t]{2}{*}{ PASS } & -0.0040 & -0.0035 \\
\hline & $(0.0416)$ & $(0.0420)$ \\
\hline \multirow[t]{2}{*}{ EDUSEC } & -26.1974 & $126.7780^{* *}$ \\
\hline & (48.4068) & (61.3991) \\
\hline \multirow[t]{2}{*}{ EDUTER } & $-301.3426^{* * *}$ & $-258.5201^{* * *}$ \\
\hline & (59.8946) & (85.9975) \\
\hline \multirow[t]{2}{*}{ UNEMPL } & $-250.2717^{* * *}$ & $-382.1196^{* * * *}$ \\
\hline & (35.5728) & (40.5778) \\
\hline \multirow[t]{2}{*}{ AGE } & 233.9317 & -303.9757 \\
\hline & $(184.0922)$ & (197.3703) \\
\hline \multirow[t]{2}{*}{ SIZE } & $2596.0170^{* *}$ & $-3331.4460^{* *}$ \\
\hline & (1234.918) & $(1607.1680)$ \\
\hline \multirow[t]{3}{*}{ Constant } & & $40773.27^{* * *}$ \\
\hline & & $(11031.400)$ \\
\hline & 111.45 & \\
\hline \multicolumn{3}{|c|}{ Hausman test } \\
\hline & {$[0.0000]$} & \\
\hline $\mathrm{R}^{2}$ & 0.7525 & 0.6297 \\
\hline Obs. & 220 & 220 \\
\hline
\end{tabular}

Note: ${ }^{* * *},{ }^{* *},{ }^{*}$ statistically significant at level $0.01,0.05$ and 0.10 .

Source: Authors' elaboration based on Bank of Italy, Eurostat and Istat data.

$80 \%$ of real assets (2013) and are largely used as a residence, but non-residential buildings and land are $6 \%$, which is approximately 540 billion Euro (Bank of Italy data). Even a share of these assets can be a useful resource, even if, for what has been said, they do not emerge in our results.

In particular, we observe that the real estate, being the result of production cycles within the system, is a component of the aggregate product but may contribute to increasing the aggregate product itself if fully employed productively and efficiently, through growth processes considered "accelerated" compared to those in which the same real assets should not be used in this manner.

A similar and additional propulsive mechanism is that related to real estate rents if they are available for productive purposes. In fact, these rents increase the collective savings (in dependence on the degree of the propensity to save) if the aggregate saving is properly stimulated and protected, adding their expansionary effect to those described above by the use of the same resources from which they derived, thus activating a desirable virtuous circle of "accelerated" growth. 


\section{Conclusions}

The net worth of consumer households is composed of many items; some of them are directly useful and included in the economic cycles, and others are unusable and could become useful under certain conditions.

The possible forms of wealth, different among countries and changing over time according to economic literature, are even greater. We can state that physical capital (e.g., machinery and equipment) and real estate properties (e.g., land to be cultivated) seem to be useful for increasing the potential economic growth rate in backward economies. Financial wealth is available for different types of investment. This easily describable and observable form of wealth is also the one that has a more direct impact on economic development in advanced economies, as noted by our analysis. Furthermore, it usually coexists with other types of immaterial wealth, which are hardly quantifiable (e.g., human capital that allows to have a greater future income, or other future flows of revenue) in advanced economies.

Despite our results showing a positive sign but a non-statistical significance of the real part of wealth in the Italian regions, our suggestion is that there are specific forms of wealth that can have the characteristics of a productive resource if properly exploited.

A share of real properties would be productive through their use by private or public companies, and the financial gains, if properly integrated into the collective savings, could contribute to productive activities by supporting private and public investments, as confirmed by the analysis on Italy. The unproductive financial wealth is instead held for transactions and for precautionary or speculative reasons.

In both circumstances, policymakers could activate appropriate mechanisms (incentives and/or taxes) aimed at the implementation of decision-making processes.

In conclusion, the productive use of private wealth can be encouraged by various economic policy interventions according to the different nature of the wealth available. Generally, real wealth is productively used and implemented with tools of tax reduction on the assets and/or on the obtainable rent; however, this type is contingent upon the use itself. On the other hand, less tax revenue may be offset, or even more than offset, by subsequent revenues from the new resulting production activities. In the case of financial wealth, interventions for productive purposes aimed at influencing owners' choices should not be considered; those aimed at the efficiency of the banking system as a whole and at the flexibility of the behavior of credit institutions would be more effective.

Our findings, in addition to the other results in the literature, highlight that there are aspects related to the wealth level and its composition that are widespread at least for homogeneous groups of countries, while other aspects depend on local behaviors and habits. The relationship between disposable income and wealth seems evident and deserving of detailed analysis, also considering the possibility of testing the above analyzed relationship in other countries. Indepth studies on the determinants of wealth inequality (Cagetti \& De Nardi, 2008) can also suggest how to promote its accumulation, e.g., by favoring financial knowledge (Lusardi et al., 2017).

This study represents a first attempt to analyze and compare the possible role of different forms of wealth, particularly their role in economic cycles. Limits of this study concern the scarce availability of data, both for long time series and for several countries or regions comparable to each other. Furthermore, a different and detailed decomposition of wealth could indicate the components best suited to the various economic purposes.

\section{References}

Aghion, P., Caroli, E., \& Garcia-Penalosa, C. (1999). Inequality and economic growth: The perspective of the new growth theories. Journal of Economic Literature, 37(4), 1615-1660.

Alesina, A., \& Perotti, R. (1996). Income distribution, political instability, and investment. European Economic Review, 40(6), 1203-1228.

Alesina, A., \& Rodrik, D. (1994). Distributive politics and economic growth. Quarterly Journal of Economics, 109(2), 465-490.

Aron, J., \& Muellbauer, J. (2013). Wealth, credit conditions, and consumption: Evidence from South Africa. Review of Income and Wealth, 59(S1), S161S196.

Arrondel, L., \& Grange, C. (2006). Transmission and 
inequality of wealth: An empirical study of wealth mobility from 1800 to 1938 in France. Journal of Economic Inequality, 4(2), 209-232.

Babeau, A., \& Sbano, T. (2003). Household wealth in the national accounts of Europe, the United States and Japan. OECD Statistics Working Paper No. 2003/02, OECD Publishing, Paris.

Bank of Italy (2015). La ricchezza delle famiglie italiane - anno 2014 [The wealth of Italian households - year 2014], n. 69, Rome.

Bao, H. X. H., \& Li, S. H. (2017). House price determinants: The roles of fundamentals and sentiments. Journal of Real Estate Practice and Education, 20(1), 63-77.

Barceló, C., \& Villanueva, E. (2016). The response of household wealth to the risk of job loss: Evidence from differences in severance payments. Labour Economics, 39(C), 35-54.

Barro, R. J., \& Sala-i-Martin, X. (1995). Economic growth. New York, NY: McGraw-Hill.

Becker, G. S., \& Tomes, N. (1979). An equilibrium theory of the distribution of income and intergenerational mobility. Journal of Political Economy, 87(6), 1153-1189.

Bell, A., \& Jones, K. (2015). Explaining fixed effects: Random effects modeling of time-series cross-sectional and panel data. Political Science Research and Methods, 3(1), 133-153.

Benabou, R. (2000). Unequal societies: Income distribution and the social contract. American Economic Review, 90(1), 96-129.

Bertaut, C. (2002). Equity prices, household wealth, and consumption growth in foreign industrial countries: Wealth effects in the 1990s. FRB International Finance Discussion Paper No. 724.

Bhattacharya, J. (1998). Credit market imperfections, income distribution, and capital accumulation. Economic Theory, 11(1), 171-200.

Borgerhoff Mulder, M., Bowles, S., Hertz, T., Bell, A., Beise, J., Clark, G., Fazzio, I., Gurven, M., Hill, K., Hooper, P. L., Irons, W., Kaplan, H., Leonetti, D., Low, B., Marlowe, F., McElreath, R., Naidu, S., Nolin, D., Piraino, P., Quinlan, R., Schniter, E., Sear, R., Shenk, M., Smith, E. A., von Rueden, C., \& Wiessner, P. (2009). Intergenerational wealth transmission and the dynamics of inequality in smallscale societies. Science, 326(5953), 682-688.

Bos, F. (2011). A national accounts satellite for human capital and education. MPRA Paper No. 33791.

Bover, O. (2010). Wealth inequality and household structure: U.S. vs. Spain. Review of Income and Wealth, 56(2), 259-290.
Boyd, J. H., \& Smith, B. D. (1997). Capital market imperfections, international credit markets, and nonconvergence. Journal of Economic Theory, 73(2), 335-364.

Brandolini, A., Cannari, L., D’Alessio, G., \& Faiella, I. (2004). Household wealth distribution in Italy in the 1990s. Bank of Italy - Temi di discussione No. 530.

Brown, S., \& Taylor, K. (2008). Household debt and financial assets: Evidence from Germany, Great Britain and the USA. Journal of the Royal Statistical Society: Series A, 171(3), 615-643.

Brun, J. F., Combes, J. L., \& Renard, M. F. (2002). Are there spillover effects between coastal and noncoastal regions in China? China Economic Review, 13(2-3), 161-169.

Buiter, W. H. (2010). Housing wealth isn't wealth. Economics: The Open-Access, Open-Assessment E-Journal, 4(22), 1-29.

Cagetti, M., \& De Nardi, M. (2008). Wealth inequality: Data and models. Macroeconomic Dynamics, 12(S2), 285-313.

Campbell, J. Y. (2006). Household finance. Journal of Finance, 61(4), 1553-1604.

Cardao-Pito, T. (2017). Classes in maximizing shareholders' wealth: Irving Fisher's theory of the economic organization in corporate financial economics textbooks. Contemporary Economics, 11(4), 369-382.

Carneiro, P., Hansen, K. T., \& Heckman, J. J. (2003). Estimating distributions of treatment effects with an application to the returns to schooling and measurement of the effects of uncertainty on college choice. International Economic Review, 44(2), 361-422.

Carroll, C. D., Otsuka, M., \& Slacalek, J. (2011). How Large Are Housing and Financial Wealth Effects? A New Approach. Journal of Money, Credit, and Banking, 43(1), 55-79.

Cartiglia, F. (1997). Credit constraints and human capital accumulation in the open economy. Journal of International Economics, 43(1-2), 221-236.

Clarke, G. R. G. (1995). More evidence on income distribution and growth. Journal of Development Economics, 47(2), 403-427.

Cooper, D., \& Dynan, K. (2016). Wealth effects and macroeconomic dynamics. Journal of Economic Surveys, 30(1), 34-55.

Cooper, E., \& Bird, K. (2012). Inheritance: a gendered and intergenerational dimension of poverty. Development Policy Review, 30(5), 527-541.

Crescenzi, R., Luca, D., \& Milio, S. (2016). The geog- 
raphy of the economic crisis in Europe: National macroeconomic conditions, regional structural factors and short-term economic performance. Cambridge Journal of Regions, Economy and Society, 9(1), 13-32.

Davies, J. B., Sandström, S., Shorrocks, A. B., \& Wolff, E. N. (2011). The level and distribution of global household wealth. The Economic Journal, 121(551), 223-254.

De Nardi, M. (2004). Wealth inequality and intergenerational links. The Review of Economic Studies, 71(3), 743-768.

Deaton, A. (1992). Understanding consumption. Oxford: Clarendon Press.

Dębski, W., \& Świderski, B. (2016). An allocation analysis of Polish household savings invested in financial assets, 2003 - 2014. Contemporary Economics, 10(2), 123-136.

Deininger, K., \& Squire, L. (1998). New ways of looking at old issues: Inequality and growth. Journal of Development Economics, 57(2), 259-287.

Démurger, S. (2001). Infrastructure development and economic growth: An explanation for regional disparities in China? Journal of Comparative Economics, 29(1), 95-117.

Di Liberto, A. (2008). Education and Italian regional development. Economics of Education Review, 27(1), 94-107.

Easterly, W. (2007). Inequality does cause underdevelopment: Insight from a new instrument. Journal of Development Economics, 84(2), 755-776.

Eicher, T. S., \& García-Penalosa, C. (2001). Inequality and growth: The dual role of human capital in development. Journal of Development Economics, 66(1), 173-197.

Elhorst, J. P. (2014) Spatial panel data models. In J.P. Elhorst (Ed.), Spatial Econometrics (pp. 37-93). Springer.

Fagerberg, J., \& Verspagen, B. (1996). Heading for divergence? Regional growth in europe reconsidered. Journal of Common Market Studies, 34(3), 431-448.

Feldstein, M. S., \& Pellechio, A. (1979). Social security and household wealth accumulation: new microeconomic evidence. The Review of Economics and Statistics, 61(3), 361-368.

Filmer, D., \& Pritchett, L. (1999). The effect of household wealth on educational attainment: Evidence from 35 countries. Population and Development Review, 25(1), 85-120.

Friedline, T., Nam, I., \& Loke, V. (2014). Households' net worth accumulation patterns and young adults' financial health: Ripple effects of the Great Reces- sion? Journal of Family and Economic Issues, 35(3), 390-410.

Gale, W. G. (1998). The effects of pensions on household wealth: A reevaluation of theory and evidence. Journal of Political Economy, 106(4), 706-723.

Galor, O., \& Moav, O. (2004). From physical to human capital accumulation: Inequality and the process of development. The Review of Economic Studies, 71(4), 1001-1026.

Galor, O., \& Zeira, J. (1993). Income distribution and macroeconomics. The Review of Economic Studies, 60(1), 35-52.

Gokhale, J., Kotlikoff, L. J., Seftonc, J., \& Weale, M. (2001). Simulating the transmission of wealth inequality via bequests. Journal of Public Economics, 79(1), 93-128.

Greco, S., Ishizaka, A., Matarazzo, B., \& Torrisi, G. (2018). Stochastic multi-attribute acceptability analysis (SMAA): an application to the ranking of Italian regions, Regional Studies, 52(4), 585-600.

Grinstein-Weiss, M., Yeo, Y. H., Zhan, M., \& Charles, P. (2008). Asset holding and net worth among households with children: Differences by household type. Children and Youth Services Review, 30(1), 62-78.

Grossmann, V. (2008). Risky human capital investment, income distribution, and macroeconomics dynamics. Journal of Macroeconomics, 30(1), 19-42.

Guiso, L., \& Sodini, P. (2013). Household finance: an emerging field. In G.M. Constantinides, M. Harris, \& R. M. Stulz, (Eds.), Handbook of the Economics of Finance - Vol. 2 (pp. 1397-1532). Elsevier.

Hanushek, E. A., \& Woessmann, L. (2012). Do better schools lead to more growth? Cognitive skills, economic outcomes, and causation. Journal of Economic Growth, 17(4), 267-321.

Hausman, J. A. (1978). Specification tests in econometrics. Econometrica, 46(6), 1251-1271.

Hong, R., Banta, J. E., \& Betancourt, J. A. (2006). Relationship between household wealth inequality and chronic childhood under-nutrition in Bangladesh. International Journal for Equity in Health, 5(15), $1-10$.

Horioka, C.Y. (2009). Do bequests increase or decrease wealth inequalities? Economics Letters, 103(1), 2325 .

Istat (2017). Annuario statistico italiano 2017 [Italian statistical yearbook 2017], Rome.

Jäntti, M., \& Sierminska, E. (2007). Survey estimates of wealth holdings in OECD countries - Evidence on the level and distribution across selected countries. UNU-WIDER Research Paper No. 2007/17.

Juselius, M., \& Takáts, E. (2015). Can demography af- 
fect inflation and monetary policy? BIS Working Papers No. 485.

Juster, F. T., Smith, J. P., \& Stafford, F. (1999) The measurement and structure of household wealth. $\mathrm{La}$ bour Economics, 6(2), 253-275.

Kaldor, N. (1955). Alternative theories of distribution. The Review of Economic Studies, 23(2), 83-100.

Keister, L. A. (2000). Race and wealth inequality: The impact of racial differences in asset ownership on the distribution of household wealth. Social Science Research, 29(4), 477-502.

Kessler, D., \& Masson, A. (1987). Personal wealth distribution in France: Cross-sectional evidence and extensions. In E.N. Wolff (Ed.), International comparisons of the distribution of household wealth (pp. 141-176). Oxford University Press.

Kessler, D., \& Wolff, E. N. (1991). A comparative analysis of household wealth patterns in France and the United States. Review of Income and Wealth, 37(3), 249-266.

Kim, J., LaTaillade, J., \& Kim, H. (2011). Family processes and adolescents' financial behaviors. Journal of Family and Economic Issues, 32(4), 668-679.

Kuznets, S. (1955). Economic growth and income inequality. The American Economic Review, 45(1), 1-28.

Langyintuo, A. S., \& Mungoma, C. (2008). The effect of household wealth on the adoption of improved maize varieties in Zambia. Food Policy, 33(6), 550559.

Lovenheim, M. F. (2011). The effect of liquid housing wealth on college enrollment. Journal of Labor Economics, 29(4), 741-771.

Lusardi, A., Michaud, P.-C., \& Mitchell, O. S. (2017). Optimal Financial Knowledge and Wealth Inequality. Journal of Political Economy, 125(2), 431-477.

Ma, C. H., \& Smith, B. D. (1996). Credit market imperfections and economic development: Theory and evidence. Journal of Development Economics, 48(2), 351-387.

Mankiw, G. N., Romer, D., \& Weil, D. (1992). A Contribution to the empirics of economic growth. Quarterly Journal of Economics, 107(2), 407-437.

Mathä T. Y., Porpiglia, A., \& Ziegelmeyer, M. (2017). Household wealth in the euro area: The importance of intergenerational transfers, homeownership and house price dynamics. Journal of Housing Economics, 35(C),1-12.

Mian, A., Rao, K., \& Sufi, A. (2013). Household balance sheets, consumption, and the economic slump. The Quarterly Journal of Economics, 128(4), 1687-1726.

Milanovic, B. (2005). Worlds apart: Measuring interna- tional and global inequality. Princeton University Press.

Morgan, S. L., \& Scott, J. C. (2007). Intergenerational transfers and the prospects for increasing wealth inequality. Social Science Research, 36(3), 11051134.

Neves, P. C., \& Silva, S. M. T. (2014). Inequality and growth: Uncovering the main conclusions from the empirics. The Journal of Development Studies, 50(1), 1-21.

Odoardi, I., \& Muratore, F. (2019a). The role of human capital after the crisis in Italy: a regional analysis. Socio-Economic Planning Sciences, 66, 58-67.

Odoardi, I., \& Muratore, F. (2019b). The North-South divergence in Italy during the Great Recession. The Manchester School, 87(1), 1-23.

Odoardi, I., Muratore, F., Bucciarelli, E., \& Chen, S.-H. (2018). Looking for regional convergence: evidence from the Italian case with multivariate adaptive regression splines. In E. Bucciarelli, S.-H. Chen, \& J.M. Corchado (Eds.), Decision Economics (pp. 7785). Springer.

Odoardi, I., \& Pagliari, C. (2011). Underground economy and income inequality: Two connected aspects in the oncoming context of Italian federalism. Global \& Local Economic Review, 15(1), 31-49.

Ozawa, M. N., \& Lee, Y. (2006). The net worth of female-headed households: A comparison to other types of households. Family Relations, 55(1), 132145.

Pasinetti, L. (1962). Rate of profit and income distribution in relation to the rate of economic growth. The Review of Economic Studies, 29(4), 267-279.

Perotti, R. (1996). Growth, income distribution, and democracy: what the data say. Journal of Economic Growth, 1(2), 149-187.

Piketty, T. (2014). Capital in the twenty-first century. Harvard University Press.

Poterba, J. M. (Ed.) (1994). International Comparisons of Household Saving. Chicago: University of Chicago Press.

Renneboog, L., \& Spaenjers, C. (2012). Religion, economic attitudes, and household finance. Oxford Economic Papers, 64(1), 103-127.

Saez, E., \& Zucman, G. (2016). Wealth inequality in the United States since 1913: Evidence from capitalized income tax data. The Quarterly Journal of Economics, 131(2), 519-578.

Semyonov, M., \& Lewin-Epstein, N. (2013). Ways to richness: determination of household wealth in 16 countries. European Sociological Review, 29(6), 1134-1148. 
Stewart, K. (2005). Dimensions of well-being in EU regions: do GDP and unemployment tell us all we need to know? Social Indicators Research, 73(2), 221-246.

Tomes, N. (1981). The family, inheritance, and the intergenerational transmission of inequality. Journal of Political Economy, 89(5), 928-958.

van Rooij, M. C. J., Lusardi, A., \& Alessie, R. J. M. (2012). Financial literacy, retirement planning and household wealth. The Economic Journal, 122(560), 449-478.

Vecchi, G. (Ed.) (2017). Measuring wellbeing. A history of Italian living standards. Oxford: Oxford University Press.

Ward, P. (2014). Measuring the level and inequality of wealth: an application to China. Review of Income and Wealth, 60(4), 613-635.

Wolff, E. N. (1981). The accumulation of household wealth over the life-cycle: A microdata analysis. Review of Income and Wealth, 27(1), 75-96.

Wolff, E. N. (1990). Methodological issues in the estimation of the size distribution of household wealth. Journal of Econometrics, 43(1-2), 179-195.

Wolff, E. N. (1996). International comparisons of wealth inequality. Review of Income and Wealth, 42(4), 433-451.

Wolff, E. N. (2014a). Household wealth trends in the United States, 1983-2010. Oxford Review of Economic Policy, 30(1), 21-43.

Wolff, E. N. (2014b). The asset price meltdown and household wealth over the Great Recession in the United States. In J. A. Bishop, \& J. G. Rodríguez (Eds.), Economic Well-Being and Inequality: Papers from the Fifth ECINEQ Meeting - Research on Economic Inequality, Vol. 22 (pp.1-42). Emerald Group Publishing Limited.

Wolff, E. N., \& Gittleman, M. (2014). Inheritances and the distribution of wealth or whatever happened to the great inheritance boom? The Journal of Economic Inequality, 12(4), 439-468.

Xie, Y., \& Jin, Y. (2015). Household wealth in China. Chinese Sociological Review, 47(3), 203-229.

Yao, R., Wang, F., Weagley, R. O., \& Liao, L. (2011). Household saving motives: Comparing American and Chinese consumers. Family and Consumer Sciences Research Journal, 40(1), 28-44. 